\title{
Effect of lipid sources and inclusion levels in diets for broiler chickens
}

[Efeito de fontes lipídicas e níveis de inclusão em dietas para frangos de corte]

\author{
G.V. Polycarpo ${ }^{1}$, V.C. Cruz $^{2}$, N.C. Alexandre ${ }^{1}$, V.B. Fascina ${ }^{1}$, I.M.G.P. Souza ${ }^{1}$, \\ J.C.M. Cravo ${ }^{3}$, R. Albuquerque ${ }^{3}$, J.R. Sartori ${ }^{1}$, A.C. Pezzato ${ }^{1}$ \\ ${ }^{1}$ Universidade Estadual Paulista - Unesp - Botucatu, SP \\ ${ }^{2}$ Universidade Estadual Paulista - Unesp - Dracena, SP \\ ${ }^{3}$ Universidade de São Paulo - USP- Pirassununga, SP
}

\begin{abstract}
This research aimed to evaluate the interactions and effects of 2 and $4 \%$ addition levels of poultry slaughterhouse fat (chicken tallow) and soybean oil in diets for broiler chickens. Two experiments were carried out using one-day-old male Cobb chicks in an entirely random design with a $2 \times 2$ factorial scheme. In the first experiment, 560 chicks were used to evaluate performance and carcass characteristics. In the second experiment, 100 chicks were used to determine the nutrient digestibility, dietary energy utilization and the lipase and amylase pancreatic activity. There was no interaction between the fat sources and the addition levels for any of the analyzed variables, except for the digestibility coefficient of dry matter (DCDM), which was higher in diets added with $2 \%$ soybean oil when compared to chicken tallow. The addition of $4 \%$ fat in the diet, regardless of fat source, improved the digestibility coefficient of ethereal extract (DCEE) and increased weight gain and feed intake. Moreover, in the initial phase, the addition of $4 \%$ fat to the diet increased lipase activity when compared to diets with $2 \%$ addition, and a positive correlation between DCEE and pancreatic lipase activity was observed. In conclusion, there is no interaction between fat sources and addition levels, except for DCDM. Carcass characteristics are not influenced by any of the studied factors. The addition of $4 \%$ fat increases pancreatic lipase activity and improves DCEE, resulting in greater weight gain, regardless of the tested fat source, making chicken tallow a great alternative to soybean oil.
\end{abstract}

Keywords: chicken tallow, lipids, soybean oil

\section{RESUMO}

O objetivo deste trabalho foi avaliar as interações e os efeitos da utilização de gordura de abatedouro avícola (gordura de frango) e de óleo de soja com níveis de inclusão de 2 e $4 \%$ em dietas para frangos de corte. Foram conduzidos dois experimentos com pintos de corte de um dia de idade, machos, da linhagem Cobb, alojados num delineamento inteiramente ao acaso em esquema fatorial $2 \times 2$. No primeiro experimento utilizaram-se 560 aves para avaliar o desempenho e as características de carcaça. No segundo experimento foram alojadas 100 aves para determinar o aproveitamento dos nutrientes e da energia da dieta, e também a atividade de lipase e amilase pancreática. Não houve interações entre as fontes lipídicas e os níveis de inclusão para nenhuma das variáveis analisadas, com exceção do coeficiente de metabolizabilidade da matéria seca (CMMS), que foi maior nas dietas com inclusão de $2 \%$ de óleo de soja em relação à gordura de frango. A inclusão de $4 \%$ de lipídios na dieta, independente da fonte lipídica, melhorou o coeficiente de metabolizabilidade do extrato etéreo (CMEE) e aumentou o ganho de peso e o consumo de ração das aves. Ainda, na fase inicial, a adição de $4 \%$ de lipídios na dieta aumentou a atividade de lipase em relação às dietas com inclusões de 2\%, observando-se uma correlação positiva entre o CMEE e a atividade de lipase pancreática. Como conclusão, não há interação entre as fontes lipídicas e os níveis de inclusão estudados, com ressalva para o CMMS. As características de carcaça não são influenciadas por nenhum dos fatores estudados. A adição de 4\% de lipídio aumenta a atividade de lipase pancreática e melhora o CMEE, refletindo em maior ganho de peso das aves, indiferentemente da fonte lipídica testada, o que torna a gordura de frango uma boa alternativa ao óleo de soja.

Palavras-chave: gordura de frango, lipídios, óleo de soja

Recebido em 14 de março de 2013

Aceito em 6 de setembro de 2013

E-mail: gupolycarpo@hotmail.com 


\section{INTRODUCTION}

The current broiler chickens demand diets with high energetic levels so that their entire genetic potential may be explored. Oils and fats are ingredients that allow a nutritionist to formulate diets with high levels of energy besides contributing with great amounts of essential fatty acids such as linolenic acid, linoleic acid and arachidonic acid. Duarte et al. (2010) attributes the benefits of lipid inclusion to the extra caloric effects that are digestion improvement, nutrient adsorption and reduction of caloric improvement, to name a few.

Metabolizable energy from oils and fats is influenced by digestibility, which depends on several factors. Some papers report that the profile of fatty acids, such as the length of the carbon chain, the number of double bonds and the fatty acid position in the glycerol molecule strongly influence digestibility (Renner and Hill, 1961; Dvorin et al., 1998; Crespo and EsteveGarcia, 2001). Lara et al. (2005) added to these factors the amount of triglycerides or free fatty acids that are present in the lipid composition. Therefore, lipid metabolism is intimately linked to the quality of the fat source in diets and may influence broiler chickens' body development.

Another factor that may influence broiler chickens' growth is the level of lipid addition to the diet as shown by Andreotti et al. (2004a), who observed an improvement in the broilers' weight gain with the addition of up to $9.63 \%$ of soybean oil. However, there are few papers that evaluate the interaction between the addition level and a tested fat source. Besides, it is necessary to update and find answers in the chickens' metabolism to explain lipid influence on productive parameters.

Therefore, the aim of this study was to evaluate the interactions and effects of 2 and $4 \%$ addition levels of poultry slaughterhouse fat (chicken tallow) and soybean oil to the diets of broiler chickens on performance, carcass characteristics, nutrient metabolism and activity of pancreatic enzymes.

\section{MATERIAL AND METHODS}

Two experiments were carried out using oneday-old male Cobb chicks that were vaccinated against Marek, Fowlpox and Gumboro. In the first experiment, 560 chicks were housed on new wood-shaving bedding in experimental aviary with 16 boxes of $1.0 \times 2.5 \mathrm{~m}$, at a density of 14 birds $/ \mathrm{m}^{2}$ in order to evaluate performance and carcass characteristics. The experiment had a completely random design with a $2 \times 2$ factorial scheme, two lipid sources (soybean oil and chicken tallow) and two addition levels (2 and $4 \%$ ) with four replications and 35 birds per experimental unit.

Within each breeding phase isonutritive and isoenergetic diets were formulated according to Rostagno et al. (2005) (Table 1). Water and feed were provided ad libitum. Bell drinkers and tubular feeders were utilized. The average maximum and minimum environmental temperatures, black globe temperatures, humid and dry indexes were $29.4 \pm 2.0^{\circ} \mathrm{C}, 23.2 \pm 2.4^{\circ} \mathrm{C}$, $28.6 \pm 2.6^{\circ} \mathrm{C}, \quad 25.6 \pm 2.1^{\circ} \mathrm{C}$ and $20.1 \pm 2,0^{\circ} \mathrm{C}$, respectively. The relative humidity of the air was $61.7 \pm 10.9 \%$. The wet bulb globe temperature index (WBGT) was 75.9 \pm 2.9 .

The performance parameters analyzed at 21 and 42 days of age were: weight gain, feed intake, feed:gain ratio, viability (100 - mortality) and productive efficiency index (PEI). Feed:gain was corrected according to the weight of the dead chickens. At the end of the experimental period (42 days), five birds were picked by replication and fasted for 8 hours. They were then insensitized and slaughtered by bleeding, plucked, and eviscerated to determine carcass yield, cuts and percentage of abdominal fat (fat tissue around the proventriculus, gizzard and cloaca). The weight of the clean eviscerated carcass (without feet, head and neck) was considered to determine carcass yield in relation to live weight at fast, obtained before slaughter. Abdominal fat was also determined in relation to live weight at fast. For the other cuts (dorsum, chest, drumstick+thigh, and wings), yield was considered in relation to eviscerated carcass weight. 
Effect of lipid sources...

Table 1. Composition and calculated values for experimental diets containing soybean oil (SO) or chicken tallow (CT) with addition of 2 or $4 \%$ in the pre-initial (1 to 7 days old), initial (8 to 21 days old), growth (22 to 35 days old) and final (36 to 42 days old) phases.

\begin{tabular}{|c|c|c|c|c|c|c|c|c|}
\hline \multirow{3}{*}{ Ingredients (\%) } & \multicolumn{8}{|c|}{ Treatments } \\
\hline & \multicolumn{2}{|c|}{ Pre initial } & \multicolumn{2}{|c|}{ Initial } & \multicolumn{2}{|c|}{ Growth } & \multicolumn{2}{|c|}{ Final } \\
\hline & SO $(2-4 \%)$ & CT $(2-4 \%)$ & $\overline{\mathrm{SO}}(2-4 \%)$ & CT $(2-4 \%)$ & $\overline{\mathrm{SO}(2-4 \%)}$ & $\overline{\mathrm{CT}(2-4 \%)}$ & $\overline{\mathrm{SO}(2-4 \%)}$ & CT $(2-4 \%)$ \\
\hline Corn & 45.76 & 45.90 & 48.81 & 48.96 & 53.06 & 53.20 & 55.09 & 55.24 \\
\hline Corn starch & $6.35-1.50$ & $6.29-1.50$ & $6.85-2.00$ & $6.79-2.00$ & $7.35-2.5$ & $7.29-2.50$ & $8.85-4.00$ & $8.79-4.00$ \\
\hline Corn gluten 60 & 0.50 & 0.50 & 1.50 & 1.50 & $2.00-4.00$ & 2.00 & 2.50 & 2.50 \\
\hline Soybean meal 45 & 37.63 & 37.60 & 33.66 & 33.64 & 28.66 & 28.63 & 24.52 & 24.49 \\
\hline Soybean oil & $2.00-4.00$ & - & $2.00-4.00$ & - & 2.00 & - & $2.00-4.00$ & - \\
\hline Chicken tallow & - & $2.00-4.00$ & - & $2.00-4.00$ & - & $2.00-4.00$ & - & $2.00-4.00$ \\
\hline Limestone & 0.65 & 0.65 & 0.61 & 0.61 & 0.56 & 0.56 & 0.52 & 0.52 \\
\hline Dicalcium phosphate & 1.95 & 1.95 & 1.82 & 1.82 & 1.66 & 1.66 & 1.52 & 1.52 \\
\hline Kaolin & $3.47-6.32$ & $3.41-6.20$ & $3.41-6.26$ & $3.35-6.14$ & $3.34-6.19$ & $3.28-6.07$ & $3.62-6.47$ & $3.56-6.35$ \\
\hline Salt & 0.51 & 0.51 & 0.49 & 0.49 & 0.46 & 0.46 & 0.44 & 0.44 \\
\hline DL-Methionine & 0.33 & 0.33 & 0.20 & 0.20 & 0.20 & 0.20 & 0.18 & 0.18 \\
\hline L-Lisine & 0.27 & 0.27 & 0.14 & 0.14 & 0.20 & 0.20 & 0.26 & 0.26 \\
\hline Threonine & 0.11 & 0.11 & 0.02 & 0.02 & 0.04 & 0.04 & 0.05 & 0.05 \\
\hline $\begin{array}{l}\text { Vitamin and mineral } \\
\text { supplement. }\end{array}$ & 0.40 & 0.40 & 0.40 & 0.40 & 0.40 & 0.40 & 0.40 & 0.40 \\
\hline Choline chloride 60 & 0.05 & 0.05 & 0.05 & 0.05 & 0.04 & 0.04 & 0.02 & 0.02 \\
\hline Allzyme SSF ${ }^{\circledR}$ & 0.02 & 0.02 & 0.02 & 0.02 & 0.02 & 0.02 & 0.02 & 0.02 \\
\hline Total & 100 & 100 & 100 & 100 & 100 & 100 & 100 & 100 \\
\hline \multicolumn{9}{|c|}{ Calculated composition (\%) } \\
\hline AMEn (kcal/kg) & \multicolumn{2}{|c|}{2,925} & \multicolumn{2}{|c|}{2,980} & \multicolumn{2}{|c|}{3,050} & \multicolumn{2}{|c|}{3,100} \\
\hline Crude protein & \multicolumn{2}{|c|}{21.850} & \multicolumn{2}{|c|}{20.650} & \multicolumn{2}{|c|}{19.100} & \multicolumn{2}{|c|}{17.740} \\
\hline Methionine dig & \multicolumn{2}{|c|}{0.634} & \multicolumn{2}{|c|}{0.506} & \multicolumn{2}{|c|}{0.485} & \multicolumn{2}{|c|}{0.458} \\
\hline Meth+Cis dig & \multicolumn{2}{|c|}{0.924} & \multicolumn{2}{|c|}{0.790} & \multicolumn{2}{|c|}{0.755} & \multicolumn{2}{|c|}{0.714} \\
\hline Lisine dig & \multicolumn{2}{|c|}{1.302} & \multicolumn{2}{|c|}{1.113} & \multicolumn{2}{|c|}{1.049} & \multicolumn{2}{|c|}{0.992} \\
\hline Threonine dig & \multicolumn{2}{|c|}{0.846} & \multicolumn{2}{|c|}{0.723} & & 682 & 0.6 & 645 \\
\hline Triptophan dig & 0.2 & & 0.2 & 226 & & 202 & 0.1 & 181 \\
\hline Calcium & 0.9 & & 0.8 & 878 & & 810 & 0.7 & 751 \\
\hline Available phosphorus & 0.4 & & 0.4 & 439 & & 405 & 0.3 & 374 \\
\hline Sodium & 0.2 & & 0.2 & 213 & & 201 & 0.1 & 191 \\
\hline Choline (mg/kg) & 30 & & 30 & 00 & & 40 & & 20 \\
\hline
\end{tabular}

${ }^{1}$ Vitamin supplement and mineral Multimix for broiler chickens in the pre-initial phase (assurance level per kg of feed): vitamin A 8,000,000 U.I., vitamin D3 2,400,000 U.I., vitamin E 12,000 U.I., vitamin K3 2,000mg, vitamin B1 2,400mg, vitamin B2 6,000mg, vitamin B6 4,000mg, vitamin B12 14,000 mcg, niacin $0.040 \mathrm{~g}$, pantothenic acid $15,000 \mathrm{mg}$, folic acid $1,000 \mathrm{mg}$, copper $0.100 \mathrm{~g}$, iron $0.050 \mathrm{~g}$, manganese $0.070 \mathrm{~g}$, zinc $0.050 \mathrm{~g}$, iodine $1,200 \mathrm{mg}$, selenium $0,200 \mathrm{mg}$, virginiamycin $15,000 \mathrm{mg}$ and B.H.T. $0.100 \mathrm{~g}$.

Vitamin supplement and mineral Multimix for broiler chickens in the initial phase (assurance level per $\mathrm{kg}$ of feed): vitamin A 7,000,000 U.I., vitamin D3 2,200,000 U.I., vitamin E 11,000 U.I., vitamin K3 1,600mg, vitamin B1 2,000mg, vitamin B2 5,000mg, vitamin B6 3,000mg, vitamin B12 12,000 mcg, niacin 35,000mg, pantothenic acid 13,000mg, folic acid 0.800mg, copper 0.100g, iron $0.050 \mathrm{~g}$, manganese $0.070 \mathrm{~g}$, zinc $0.050 \mathrm{~g}$, iodine $1,200 \mathrm{mg}$, selenium $0.200 \mathrm{mg}$, Chloro hyidroxy quinoline $30,000 \mathrm{mg}$, monensin $0.100 \mathrm{~g}$, and B.H.T. $0.100 \mathrm{~g}$.

Vitamin supplement and mineral Multimix for broiler chickens in the growth phase (assurance level per $\mathrm{kg}$ of feed): vitamin A 6,000,000 U.I., vitamin D3 2,000,000 U.I., vitamin E 10,000 U.I., vitamin K3 1,600mg, vitamin B1 1,400mg, vitamin B2 4,000mg, vitamin B6 2,000mg, vitamin B12 10,000 mcg, niacin 30,000mg, pantothenic acid 11,000mg, folic acid 0.600mg, copper 0.100g, iron $0.050 \mathrm{~g}$, manganese $0.070 \mathrm{~g}$, zinc $0.050 \mathrm{~g}$, iodine $1,200 \mathrm{mg}$, selenium $0.200 \mathrm{mg}$, Chloro hydroxyl quinoline $30,000 \mathrm{mg}$, salinomycin $0.060 \mathrm{~g}$, and B.H.T. 0.100g.

Vitamin supplement and mineral Multimix for broiler chickens in the final phase (assurance level per $\mathrm{kg}$ of feed): vitamin A 5,000,000 U.I., vitamin D3 1,000,000 U.I., vitamin E 8,000 U.I., vitamin K3 1,600mg, vitamin B2 2,000mg, vitamin B12 5,000 mcg, niacin 20,000mg, pantothenic acid 9,000mg, copper $8,000 \mathrm{mg}$, iron $0.050 \mathrm{~g}$, manganese $0.070 \mathrm{~g}$, zinc $0.050 \mathrm{~g}$, iodine $1,200 \mathrm{mg}$, selenium $0.200 \mathrm{mg}$ and B.H.T. $15,000 \mathrm{mg}$.

In the second experiment 100 chicks were housed in a climate-controlled chamber with 20 metabolism cages (five birds/cage). Each cage represented an experimental unit and had a trough feeder, nipple drinkers and excretion collection trays. The metabolic assays were carried out during two periods: 11 to 21 days old and 25 to 35 days old with five days of adaptation to experimental diets and five days to collect excreta.

Until the beginning of the experimental period the chicks were bred under the same management and feeding conditions. At 10 days 
old the chicks were redistributed in the cages according to their weight, and each cage represented an experimental unit under the same conditions. The experimental design and diets were the same as in the first experiment, with five replications.

The metabolic assays were carried out by the method of total excreta collection. They were collected twice a day ( $8 \mathrm{~h} 00$ and $16 \mathrm{~h} 00)$ for five days, bagged in plastic bags, identified by replication and stored in a freezer $\left(-16^{\circ} \mathrm{C}\right)$. At the end of each experimental period the amount of ingested feed, as well as the amount of total produced excreta was determined.

The excreta were then gathered by replication, thawed, weighed, homogenized, and a $10 \%$ sample was separated and weighed, then placed in an air stove at $55^{\circ} \mathrm{C}$ for 72 hours for predrying. Later the samples were exposed to air in order to balance ambient temperature and humidity. They were then weighed and ground and the humidity, nitrogen, ethereal extract of excreta and ration contents were determined according to the methodology described by Silva and Queiroz (2002) to obtain the digestibility coefficient of dry matter (DCDM), nitrogen (DCN) and ethereal extract (DCEE). Crude energy was measured using a calorimetric pump $\left(\mathrm{Ika}^{\circledR}-\right.$ Werke, Model C2000), and the nitrogencorrected apparent metabolizable energy value (AMEn) was calculated using the equations proposed by Matterson et al. (1965).

At 21 and 35 days old, the pancreas of one chick from each experimental unit was collected and weighed to measure the lipase and amylase pancreatic activity. Soon after being collected and weighed the organ was quickly stored in liquid nitrogen for posterior homogenization in a buffer solution of $50 \mathrm{mM}$ Tris- $\mathrm{HCl}, \mathrm{pH} 8$, containing $50 \mathrm{mM} \mathrm{CaCl}_{2}$ in a $1: 20$ ratio (weight:volume). Amylase was determined with the iodometric method (commercial kit) in which an amylase unit is the amount of enzyme that hydrolyzes $10 \mathrm{mg}$ of starch in 30 minutes. Lipase activity was determined with the colorimetric method in which lipase hydrolyzes thioester, producing thioalcohol that reacts with nitrobenzoic acid and releases a yellow anion. The color intensity is proportional to the enzyme concentration. The reading was done in a spectrophotometer at 660 and $420 \mathrm{~nm}$, for amylase and lipase, respectively. Enzyme activity was expressed in international units (U.I.) per milligram of tissue.

Statistical analyses were done through the Statistical Analysis System (Statistical..., 2008) at $5 \%$ significance. The results were submitted to analysis of variance by PROC MIXED, and, when necessary, the treatment means were compared by the Tukey test. PROC PEARSON was utilized to verify the correlation between DCEE and lipase activity.

\section{RESULTS AND DISCUSSION}

The average initial weight of the chicks was $44.56 \mathrm{~g}$. In experiment 1 there was no interaction between the fat sources and the addition levels on the performance at 21 and 42 days old (Tables 2 and 3). The lipid sources did not influence performance in both studied ages, corroborating with previous studies (Pesti et al., 2002; Lara et al., 2005; Duarte et al., 2010) that also showed similar performance for chicken fed with soybean oil and chicken tallow. That can be attributed to the great amount of unsaturated and polyunsaturated fatty acids in chicken tallow when compared to other animal fat sources (Centenaro et al., 2008), making it an excellent alternative to soybean oil.

Chicks fed with a $4 \%$ fat diet presented greater weight gain and feed intake when compared to the ones fed a $2 \%$ fat diet at 21 and 42 days old, showing that the body development of chickens and intake increased while fat addition levels to the diet increased, regardless of the source. These results are in accordance with other studies which showed that greater levels of oil added to feed benefit chickens' growth (Raber et al., 2009). Considering that the diets were isonutritive, the improvement of weight gain is due to the replacement of carbohydrate (starch) by fat, showing fat superiority in chickens' weight gain compared to carbohydrates, possibly improved by the increase of feed intake, consequently resulting in greater nutrient intake (Pucci et al., 2003; Andreotti et al., 2004a). Still, it is important to point out that oils and fats present lower caloric increase than carbohydrates during digestion, destining greater amounts of energy to maintenance and production demands. 
Effect of lipid sources...

Table 2. Performance of 21-day-old broiler chickens fed diets with addition of 2 or $4 \%$ soybean oil (S) or chicken tallow $(\mathrm{T})$

\begin{tabular}{lcccccc}
\hline \multirow{2}{*}{ Effect } & & \multicolumn{5}{c}{ Performance 1 to 21 days } \\
\cline { 2 - 6 } & $\mathrm{S}$ & $\mathrm{AIW}^{1}$ & $\mathrm{WG}$ & FI & F:G & VB \\
\hline Lipid $^{2}$ & $\mathrm{~T}$ & 44.54 & 963 & 1332 & 1.389 & 97.50 \\
& $2 \%$ & 44.54 & 950 & 1321 & 1.397 & 96.43 \\
Level & $4 \%$ & 44.58 & 939 & 1308 & 1.400 & 96.79 \\
& $\mathrm{~S} \mathrm{2 \%}$ & 44.60 & 938 & 1307 & 1.385 & 97.14 \\
Lipid*Level & $\mathrm{S} \mathrm{4 \%}$ & 44.48 & 987 & 1358 & 1.378 & 97.86 \\
& $\mathrm{~T} 2 \%$ & 44.48 & 939 & 1309 & 1.401 & 96.43 \\
& $\mathrm{~T} 4 \%$ & 44.67 & 961 & 1332 & 1.392 & 96.43 \\
\hline Probability & & & & & & \\
Lipid & & 0.8104 & 0.1522 & 0.3261 & 0.3215 & 0.5919 \\
Level & & 0.8104 & 0.0011 & 0.0063 & 0.0893 & 0.8577 \\
Lipid*Level & & 0.3264 & 0.1443 & 0.2317 & 0.5037 & 0.8567 \\
\hline SEM & & 0.0692 & 6.3576 & 7.2573 & 0.0042 & 0.8831 \\
\hline
\end{tabular}

${ }^{1} \mathrm{AIW}$, average initial weight $(\mathrm{g})$; WG, weight gain $(\mathrm{g})$; FI, feed intake (g); F:G, feed:gain ratio; VB, viability (\%).

${ }^{2} \mathrm{~S}$, soybean oil; $\mathrm{T}$, chicken tallow.

${ }^{3}$ SEM, standard error mean.

Table 3. Performance of 42-day-old broiler chickens fed diets with addition of 2 or $4 \%$ soybean oil (S) or chicken tallow (T)

\begin{tabular}{lcccccc}
\hline \multirow{2}{*}{ Effect } & & \multicolumn{5}{c}{ Performance 1 to 42 days } \\
\cline { 3 - 7 } & $\mathrm{S}$ & $\mathrm{WG}^{1}$ & $\mathrm{FI}$ & $\mathrm{F}: \mathrm{G}$ & $\mathrm{VB}$ & PEI \\
\hline Lipid $^{2}$ & $\mathrm{~T}$ & 2701 & 4727 & 1.762 & 92.14 & 336.29 \\
& $2 \%$ & 2657 & 4678 & 1.737 & 91.43 & 341.38 \\
Level & $4 \%$ & 2768 & 4827 & 1.737 & 93.93 & 342.13 \\
& $\mathrm{~S} \mathrm{2 \%}$ & 2659 & 4634 & 1.762 & 89.64 & 335.54 \\
Lipid*Level & $\mathrm{S} \mathrm{4 \%}$ & 2743 & 4821 & 1.771 & 95.00 & 343.39 \\
& $\mathrm{~T} 2 \%$ & 2654 & 4523 & 1.722 & 92.86 & 340.88 \\
& $\mathrm{~T} 4 \%$ & 2792 & 4834 & 1.753 & 90.00 & 341.88 \\
\hline Probability & & & & & & \\
Lipid & & 0.4476 & 0.4990 & 0.3771 & 0.7475 & 0.6153 \\
Level & & 0.0017 & 0.0042 & 0.3631 & 0.0708 & 0.5167 \\
Lipid*Level & & 0.3519 & 0.3954 & 0.8189 & 0.5217 & 0.4562 \\
\hline SEM & & 19.3923 & 46.1494 & 0.0128 & 1.1334 & 4.6482 \\
\hline
\end{tabular}

${ }^{1} \mathrm{WG}$, weight gain (g); FI, feed intake (g); F:G, feed:gain ratio; VB, viability (\%); PEI, productive efficiency index $(((\mathrm{VB} * \mathrm{GPD}) / \mathrm{CA}) / 10)$.

${ }^{2} \mathrm{~S}$, soybean oil; $\mathrm{T}$, chicken tallow.

${ }^{3}$ SEM, standard error mean.

Feed:gain ratio was not influenced in both periods because the broilers that presented greater body growth also presented more feed intake due to the higher density:volume (Raber et al., 2009) and better palatability (Lara et al., 2005; Duarte et al., 2010) of diets containing greater amounts of lipid. Viability and productive efficiency index were not influenced by the treatments.
The studied diets did not influence carcass yield, cuts and abdominal fat content of chickens (Table 4). These results are similar to the ones found in literature (Lara et al., 2006; Duarte et al., 2010), which did not show any difference in the carcass characteristics of chickens fed with different fat sources. 
Table 4. Carcass yield, cuts and abdominal fat content of 42-day-old broiler chickens fed diets with addition of 2 or $4 \%$ soybean oil (S) or chicken tallow (T)

\begin{tabular}{|c|c|c|c|c|c|c|c|}
\hline \multirow{2}{*}{ Effect } & & \multicolumn{5}{|c|}{ Carcass characteristics } & \multirow[b]{2}{*}{ WngY } \\
\hline & & $\mathrm{CarcY}^{1}$ & AbdF & DrsmY & ChstY & Dtck+ThY & \\
\hline \multirow[t]{2}{*}{ Lipid $^{2}$} & $S$ & 75.82 & 1.73 & 20.14 & 38.58 & 30.23 & 10.77 \\
\hline & $\mathrm{T}$ & 76.82 & 1.82 & 20.10 & 38.59 & 30.31 & 10.69 \\
\hline \multirow[t]{2}{*}{ Level } & $2 \%$ & 76.78 & 1.74 & 20.04 & 38.41 & 30.40 & 10.75 \\
\hline & $4 \%$ & 75.86 & 1.82 & 20.20 & 38.77 & 30.13 & 10.71 \\
\hline \multirow[t]{4}{*}{ Lipid*Level } & $\mathrm{S} 2 \%$ & 76.02 & 1.66 & 20.24 & 38.23 & 30.46 & 10.77 \\
\hline & $\mathrm{S} 4 \%$ & 75.62 & 1.81 & 20.05 & 38.93 & 30.00 & 10.78 \\
\hline & $\mathrm{T} 2 \%$ & 77.53 & 1.81 & 19.85 & 38.57 & 30.35 & 10.73 \\
\hline & $\mathrm{T} 4 \%$ & 76.11 & 1.83 & 20.35 & 38.61 & 30.27 & 10.65 \\
\hline \multicolumn{8}{|l|}{ Probability } \\
\hline Lipid & & 0.5144 & 0.4690 & 0.8379 & 0.9806 & 0.6562 & 0.3445 \\
\hline Level & & 0.5518 & 0.5091 & 0.4602 & 0.2838 & 0.1455 & 0.6992 \\
\hline Lipid*Level & & 0.7385 & 0.5760 & 0.1019 & 0.3352 & 0.3127 & 0.5740 \\
\hline SEM $^{3}$ & & 0.7515 & 0.0603 & 0.1031 & 0.1678 & 0.0926 & 0.0439 \\
\hline
\end{tabular}

${ }^{\mathrm{T}} \mathrm{CarcY}$, carcass yield (\%); AbdF, abdominal fat (\%); DrsmY, dorsum yield (\%); ChstY, chest yield (\%); Dtck+ThY, drumstick + thigh yield (\%); WngY, wing yield (\%).

${ }^{2} \mathrm{~S}$, soybean oil; $\mathrm{T}$, chicken tallow.

${ }^{3} \mathrm{SEM}$, standard error mean.

However, differently from the findings in this study, some researchers have demonstrated that the level of fat addition to the diet may cause variation in the chickens' abdominal fat content (Crespo and Esteve-Garcia, 2001; Andreotti et al., 2004a), as well as the saturation level of different lipid sources (Crespo and EsteveGarcia, 2001; Crespo and Esteve-Garcia, 2002; Villaverde et al., 2005; Wongsuthavas et al., 2008; Ferrini et al., 2008). According to Ferrini et al. (2008), chickens fed polyunsaturated fatty acids presented a $30 \%$ reduction of abdominal fat when compared to chickens that had saturated fatty acids. It was not possible to observe those results in this study, probably due to the source of animal fat that was used, rich in unsaturated and polyunsaturated fatty acids. According to Chiu and Gioielli (2002), a chicken's abdominal fat consists of $67.2 \%$ of unsaturated and polyunsaturated fatty acids which are $37.5 \%$ oleic acid, $21.2 \%$ linolic acid, $7.3 \%$ palmitoleic acid and $1.2 \% \alpha$-linolenic acid. Later, Chiu and Gioielli (2008) published similar fatty acids values in the composition of chicken tallow: $43.4 \%$ oleic acid, $17.2 \%$ linolic acid, $7.1 \%$ palmitoleic acid and $1.0 \% \alpha$-linolenic acid.

In the metabolic assay (experiment 2) of the initial phase (16 to 21 days old), no interaction between the studied factors was observed (Table 5). The diets with $4 \%$ fat presented lower DCDM, which seems to be related to the greater amount of inert material (kaolin) added to these diets to keep them isonutritive. In the growth phase (30-35 days), interaction between lipid sources and inclusion levels in DCDM was observed (Table 6). Soybean oil provided higher DCDM than chicken tallow with $2 \%$ addition.

DCEE improved in both periods with $4 \%$ fat addition regardless of the fat source used, explaining the greater weight gain of the chickens that were fed with these diets in the performance experiment, once the broiler chickens that were fed more fat presented greater weight gain. DCEE improvement, only due to greater levels and not due to the quality of oils and fat added to the diet, are in accordance to the results found by Vieira et al. (2002) and Raber et al. (2009).

DCN and AMEn variables were not influenced by the diets. This information disagrees with Pesti et al. (2002) who observed a difference in the content of metabolizable energy of two sources of chicken tallow compared to soybean oil. However, the findings by Raber et al. (2009) corroborate the data from this study because they report that the use of diets with $8 \%$ soybean oil compared to $4 \%$ did not change the energy digestibility coefficient. Andreotti et al. (2004b), studying additions of $0.0,3.3,6.6$ and $9.9 \%$ of soybean oil in the diet of broiler chickens did not verify any difference in the values of digestible energy of rations in the growth and final phases. 
Effect of lipid sources...

Table 5. Metabolism of broiler chickens' diet nutrients in the initial phase (16 to 21 days) with addition of 2 or $4 \%$ soybean oil $(\mathrm{S})$ or chicken tallow (T)

\begin{tabular}{lccccc}
\multirow{2}{*}{ Effect } & & \multicolumn{3}{c}{ Metabolism, initial phase } \\
\cline { 2 - 5 } & $\mathrm{S}$ & DCDM $^{1}$ & DCEE & DCN & AMEn \\
\hline Lipid $^{2}$ & $\mathrm{~T}$ & 69.00 & 91.98 & 57.96 & 71.52 \\
& $2 \%$ & 68.45 & 91.68 & 55.94 & 70.94 \\
Level & $4 \%$ & 70.44 & 91.00 & 56.96 & 71.61 \\
& $\mathrm{~S} \%$ & 67.00 & 92.66 & 56.94 & 70.85 \\
Lipid*Level & $\mathrm{S} \mathrm{4 \%}$ & 70.80 & 91.17 & 57.78 & 71.76 \\
& $\mathrm{~T} \%$ & 67.19 & 92.79 & 58.13 & 71.28 \\
& $\mathrm{~T} \mathrm{4 \%}$ & 70.08 & 90.83 & 56.14 & 71.46 \\
& & 66.82 & 92.53 & 55.74 & 70.42 \\
\hline Probability & & & & & \\
Lipid & & 0.6377 & 0.5718 & 0.0941 & 0.5564 \\
Level & & 0.0085 & 0.0062 & 0.9815 & 0.4444 \\
Lipid*Level & 0.8816 & 0.9328 & 0.7435 & 0.7759 \\
\hline SEM & & 0.6602 & 0.3096 & 0.5711 & 0.4597 \\
\hline
\end{tabular}

${ }^{1}$ DCDM, digestibility coefficient of dry matter (\%); DCEE, digestibility coefficient of ethereal extract (\%); DCN, digestibility coefficient of nitrogen (\%); AMEn, nitrogen-corrected apparent metabolizable energy (\%).

${ }^{2} \mathrm{~S}$, soybean oil; $\mathrm{T}$, chicken tallow.

${ }^{3} \mathrm{SEM}$, standard error mean.

Table 6. Metabolism of broiler chickens' diet nutrients in the growth phase (30 to 35 days) with addition of 2 or $4 \%$ soybean oil (S) or chicken tallow (T)

\begin{tabular}{lccccc}
\hline \multirow{2}{*}{ Effect } & & \multicolumn{3}{c}{ Metabolism, growth phase } \\
\cline { 2 - 6 } & $\mathrm{S}$ & $\mathrm{DCDM}^{1}$ & $\mathrm{DCEE}$ & $\mathrm{DCN}$ & AMEn \\
\hline Lipid $^{2}$ & $\mathrm{~T}$ & 71.69 & 90.05 & 57.18 & 74.27 \\
& $2 \%$ & 71.09 & 90.53 & 55.25 & 74.12 \\
Level & $4 \%$ & 72.44 & 88.44 & 57.25 & 74.21 \\
& $\mathrm{~S} \%$ & $73.23 \mathrm{aA}^{3}$ & 92.15 & 55.18 & 74.18 \\
Lipid*Level & $\mathrm{S} 4 \%$ & $70.14 \mathrm{bA}$ & 87.75 & 59.12 & 74.44 \\
& $\mathrm{~T} 2 \%$ & $71.64 \mathrm{aB}$ & 89.35 & 55.24 & 74.11 \\
& $\mathrm{~T} 4 \%$ & $70.54 \mathrm{aA}$ & 91.94 & 55.39 & 73.98 \\
& & & & 55.11 & 74.25 \\
\hline Probability & & 0.1376 & 0.3824 & 0.1530 & 0.7148 \\
Lipid & & $<0.0001$ & $<0.0001$ & 0.1264 & 0.9535 \\
Level & & 0.0188 & 0.1150 & 0.1829 & 0.4860 \\
Lipid*Level $^{\text {SEM }}$ & & 0.3256 & 0.5045 & 0.7046 & 0.1975 \\
\hline
\end{tabular}

${ }^{1}$ DCDM, digestibility coefficient of dry matter (\%); DCEE, digestibility coefficient of ethereal extract (\%); DCN, digestibility coefficient of nitrogen (\%); AMEn, nitrogen-corrected apparent metabolizable energy (\%).

${ }^{2} \mathrm{~S}$, soybean oil; $\mathrm{T}$, chicken tallow.

${ }^{3}$ Different lower case letters in level comparison and capital letters in the fat sources differ by Tukey's test $(\mathrm{P}<0.05)$.

${ }^{4}$ SEM, standard error mean.

There was no interaction between the factors for the activity of pancreatic enzymes (Table 7). Amylase activity was not influenced by the treatments. Only the level of fat addition to the diet influenced lipase activity at 21 days old, where diets with $4 \%$ fat presented higher lipase activity. This behavior supports the hypothesis that chickens modulate enzyme production in a specific way, according to the amount of substrate in the gastrointestinal tract instead of keeping the enzyme activity constantly high (Pinheiro et al., 2004). Sakomura et al. (2004) described that the extrusion process of whole soybean increased the lipase activity of broiler chickens in the fourth week of age due to the greater oil exposure caused by the process. According to Rodwell (1990), the substrate acts directly in the enzymatic activity of lipase since it is an inductive enzyme. However, at 35 days old, there was no difference in lipase activity, 
probably in consequence of the pancreas maturation, a phenomenon that occurs in the organs of the digestive system of birds with time, until the organs reach full development to meet all the physiological needs.

Table 7. Pancreatic enzyme activity (U.I./mg of tissue) in broiler chickens at 21 and 35 days old fed diets with addition of 2 or $4 \%$ soybean oil (S) or chicken tallow (T)

\begin{tabular}{|c|c|c|c|c|c|}
\hline \multirow{3}{*}{ Effect } & & \multicolumn{4}{|c|}{ Pancreatic enzyme activity } \\
\hline & & \multicolumn{2}{|c|}{21 days } & \multicolumn{2}{|c|}{35 days } \\
\hline & & Lipase & Amylase & Lipase & Amylase \\
\hline \multirow[t]{2}{*}{ Lipid $^{1}$} & $\mathrm{~S}$ & 0.0534 & 26.59 & 0.0419 & 29.76 \\
\hline & $\mathrm{T}$ & 0.0566 & 27.33 & 0.0399 & 30.36 \\
\hline \multirow[t]{2}{*}{ Level } & $2 \%$ & 0.0430 & 25.68 & 0.0426 & 30.29 \\
\hline & $4 \%$ & 0.0670 & 28.24 & 0.0393 & 29.84 \\
\hline \multirow[t]{4}{*}{ Lipid*Level } & $\mathrm{S} 2 \%$ & 0.0406 & 25.45 & 0.0438 & 30.15 \\
\hline & $\mathrm{S} 4 \%$ & 0.0661 & 27.73 & 0.0400 & 29.38 \\
\hline & $\mathrm{T} 2 \%$ & 0.0453 & 25.92 & 0.0413 & 30.42 \\
\hline & $\mathrm{T} 4 \%$ & 0.0679 & 28.74 & 0.0386 & 30.30 \\
\hline \multicolumn{6}{|l|}{ Probability } \\
\hline Lipid & & 0.5459 & 0.6510 & 0.7028 & 0.8426 \\
\hline Level & & 0.0003 & 0.1319 & 0.5293 & 0.8835 \\
\hline Lipid*Level & & 0.7828 & 0.8675 & 0.9109 & 0.9146 \\
\hline SEM $^{2}$ & & 0.0037 & 0.7995 & 0.0024 & 1.3708 \\
\hline
\end{tabular}

${ }^{\mathrm{T}} \mathrm{S}$, soybean oil; T, chicken tallow.

${ }^{2} \mathrm{SEM}$, standard error mean.

Evaluating a correlation between DCEE and lipase activity, it is observed that the effect between these variables in the initial breeding phase was positive (Table 8). Freitas et al. (2005) relate DCEE with the production of pancreatic lipase and bile, explaining that lower DCEE in chickens in relation to roosters may be due to the lower lipase production in young chickens. Sakomura et al. (2004) mention that they also observed a positive correlation between the digestibility of ethereal extract of soybean and lipase activity, corroborating the findings in this study.

Table 8. Correlation between the activity of pancreatic lipase activity and the digestibility coefficient of ethereal extract (DCEE) at 21 days old (initial phase) and 35 days old (growth phase)

\begin{tabular}{|c|c|c|}
\hline \multicolumn{2}{|c|}{ Parameters } & Probability \\
\hline $\begin{array}{ll}\text { Initial } & \\
& \text { Lipase }\end{array}$ & $\begin{array}{c}\text { DCEE }^{1} \\
0.55119\end{array}$ & 0.0118 \\
\hline $\begin{array}{l}\text { Growth } \\
\quad \text { Lipase }\end{array}$ & $\begin{array}{c}\text { DCEE } \\
-0.10255\end{array}$ & 0.6670 \\
\hline
\end{tabular}

${ }^{1}$ DCEE, digestibility coefficient of ethereal extract.

\section{CONCLUSION}

It is verified that there is no interaction in the use of chicken tallow and soybean oil with addition levels of 2 and $4 \%$ in the diet, except for DCDM, which is higher in the growth period in the diets with $2 \%$ addition of soybean oil in relation to chicken tallow. For the other metabolism nutrient variables, performance, carcass characteristics and pancreatic enzyme activity, chicken tallow has similar results to soybean oil, characterized as an excellent alternative in broiler chickens' feeding. The addition of $4 \%$ fat examined in this study increased chickens' intake and weight gain as well as improved DCEE of rations and pancreatic lipase activity at 21 days old. Moreover, a positive correlation is observed between DCEE and lipase activity in the initial phase. 


\section{ACKNOWLEDGEMENTS}

We thank FAPESP for financing this study (Process $n^{\circ}$ 2010/07789-0), for the master's program scholarship (Process $n^{\circ}$ 2010/03758-3) and for the scientific initiation scholarship (Process 2010/15780-3). And we thank Korin Agropecuária Ltda. for providing chicken tallow.

\section{REFERENCES}

ANDREOTTI, M.O.; JUNQUEIRA, O.M.; BARBOSA, M.J.B. et al. Tempo de trânsito intestinal, desempenho, característica de carcaça e composição corporal de frangos de corte alimentados com rações isoenergéticas formuladas com diferentes níveis de óleo de soja. Rev. Bras. Zootec., v.33, p.870-879, 2004a.

ANDREOTTI, M.O.; JUNQUEIRA, O.M.; BARBOSA, M.J.B. et al. Energia metabolizável do óleo de soja em diferentes níveis de inclusão para frangos de corte nas fases de crescimento e final. Rev. Bras. Zootec., v.33, p.1145-1151, 2004b.

CENTENARO, G.S.; FURLAN, V.J.M.; SOUZA-SOARES, L.A. Gordura de frango: alternativas tecnológicas e nutricionais. Semina Cienc. Agrar., v.29, p.619-630, 2008.

CHIU, M.C.; GIOIELLI, L.A. Conteúdo de gordura sólida da gordura abdominal de frango, de suas estearinas e de suas misturas binárias com toucinho. Cienc. Tecnol. Aliment., v.22, p.151-157, 2002.

CHIU, M.C.; GIOIELLI, L.A. Lipídios estruturados obtidos a partir da mistura de gordura de frango, sua estearina e triacilglicerois de cadeia média. i- composição em ácidos graxos e em triacilglicerois. Quim. Nova, v.31, p.232237,2008

CRESPO, N.; ESTEVE-GARCIA, E. Dietary fatty acid profile modifies abdominal fat deposition in broiler chickens. Poult. Sci., v.80, p.71-78, 2001.

CRESPO, N.; ESTEVE-GARCIA, E. Dietary linseed oil produces lower abdominal fat deposition but higher de novo fatty acid synthesis in broiler chickens. Poult. Sci., v.81, p.1555-1562, 2002.
DUARTE, F.D.; LARA, L.J.C.; BAIÃO, N.C. $e t$ al. Efeito da inclusão de diferentes fontes lipídicas em dietas para frangos de corte sobre o desempenho, rendimento e composição da carcaça. Arq. Bras. Med. Vet. Zootec., v.62, p.439-444, 2010.

DVORIN, A.; ZOREF, Z.; MOKADY, S. et al. Nutritional aspects of hydrogenated and regular soybean oil added to diets of broiler chickens. Poult. Sci., v.77, p.820-825, 1998.

FERRINI, G.; BAUCELLS, M.D.; ESTEVEGARCIA, E. et al. Dietary polyunsaturated fat reduces skin fat as well as abdominal fat in broiler chickens. Poult. Sci., v.87, p.528-535, 2008.

FREITAS, E.R.; SAKOMURA, N.K.; NEME, R. et al. Valor energético do óleo ácido de soja para aves. Pesq. Agropec. Bras., v.40, p.241-246, 2005.

LARA, L.J.C.; BAIÃO, N.C.; AGUILAR, C.A.L. et al. Efeito de fontes lipídicas sobre o desempenho de frangos de corte. Arq. Bras. Med. Vet. Zootec., v.57, p.792-798, 2005.

LARA, L.J.C.; BAIÃO, N.C.; AGUILAR, C.A.L. et al. Rendimento, composição e teor de ácidos graxos da carcaça de frangos de corte alimentados com diferentes fontes lipídicas. Arq. Bras. Med. Vet. Zootec., v.58, p.108-115, 2006.

MATTERSON, L.D.; POTTER, L.M.; STUTZ, N.W. et al. The metabolizable energy of feeds ingredients for chikens. Connecticut: UNICONN PRESS, 1965. 11p.

PESTI, G.M.; BAKALLI, R.I.; QIAO, M. et al. A comparison of eight grades of fat as broiler feed ingredients. Poult. Sci., v.82, p.382-390, 2002.

PINHEIRO, D.F.; CRUZ, V.C.; SARTORI, J.R. et al. Effect of early feed restriction and enzyme supplementation on digestive enzyme activities in broilers. Poult. Sci., v.83, p.1544-1550, 2004.

PUCCI, L.E.A; RODRIGUES, P.B.; FREITAS, R.T.F. et al. Níveis de óleo e adição de complexo enzimático na ração de frangos de corte. Rev. Bras. Zootec., v.32, p.909-917, 2003.

RABER, M.R.; RIBEIRO, A.M.L.; KESSLER, A.M. et al. Suplementação de glicerol ou de lecitina em diferentes níveis de ácidos graxos livres em dietas para frangos de corte. Cienc. Anim. Bras., v.10, p.745-753, 2009. 
RENNER, R.; HILL, F.W. Factors affecting the absorbability of saturated fatty acids in the chick. J. Nutr., v.74, p.254-258, 1961.

RODWELL, V.M. Enzimas: regulação da atividade. In: HARPER, H.A. (Ed.). Bioquímica. São Paulo: ATENEU, 1990. p.84-94.

ROSTAGNO, H.S.; ALBINO, L.F.T.; DONZELE, J.L. et al. Tabelas brasileiras para aves e suínos: composição de alimentos $\mathrm{e}$ exigências nutricionais. 2.ed. Viçosa: UFV, 2005. 186p.

SAKOMURA, N.K.; BIANCHI, M.D.; PIZAURO JUNIOR., J.M. et al. Efeito da idade dos frangos de corte na atividade enzimática e digestibilidade dos nutrientes do farelo de soja e da soja integral. Rev. Bras. Zootec., v.33, p.924935, 2004.

SILVA, D.J.; QUEIROZ, A.C. Análise de alimentos: métodos químicos e biológicos. 3.ed. Viçosa: UFV, 2002. 165p.
STATISTICAL Analisis System - SAS Institute Inc. 2008. SAS/STAT ${ }^{\circledR} 9.2$ User's Guide. Cary, NC, USA: SAS Institute Inc.

VIEIRA, S.L.; RIBEIRO, A.M.L.; KESSLER, A.M. et al. Utilização da energia de dietas para frangos de corte formuladas com óleo ácido de soja. Rev. Bras. Cienc. Avic., v.4, p.1-13, 2002.

VILLAVERDE， C.; BAUCELLS， M.D.; CORTINA, L. et al. Chemical composition and energy content of chickens in response to different levels of dietary polyunsaturated fatty acids. Arch Anim Nutr., v.59, p.281-292, 2005.

WONGSUTHAVAS, S.; TERAPUNTUWA, S.; WONGSRIKEA, W. et al. Influence of amount and type of dietary fat on deposition, adipocyte count and iodine number of abdominal fat in broiler chickens. J. Anim. Physiol. An. N, v.92, p.92-98, 2008. 